3. Bifurcation and intercalation of the ripple marks takes place in both directions along the strike.

4. The ripple marks are asymmetrical in a consistent direction.

5. Beachrocks are usually composed of calcarenite or coarser material not lutite; beachrocks are usually stratified-there is no stratification in the Northumberland structures; beachrocks are usually produced with gentle inclinations and show discordant relationships with overlying sedimentssuch features are not found.

It is presumed that the calcilutite was partially cohesive so that the steep crest slopes of the ripples could be maintained; such agglutination of grains has, for instance, been described on the Bahama Banks by Illing (1954. The depositional environment of the carbonate rocks of this part of the succession in North Northumberland as deduced from sedimentological and biological evidence is one of quiescent conditions possibly in a restricted embayment. There is no evidence whatsoever of either high turbulence of the water or of partial emergence of the sea floor and the suggestion put forward by Barnes can therefore be rejected both on observational detail and in consideration of the regional picture.

K. A. G. Shrells.

Department of Geology,

UNIVERSITY OF GLASGOW.

9th March, 1964.

\title{
DEPOSITIONAL ENVIRONMENT OF PURBECK FORMATION
}

SIR,- The depositional environment of the Lower Purbeck Formation, long thought to be fresh or brackish water, has recently been re-interpreted from faunal evidence as marine (Brown, Geol. Mag., 100, 565-573). Geochemical data from the Middle and Upper Purbeck (Walker, 1962, 1963) also supports this interpretation. The boron content of illite in sedimentary rocks is believed to reflect palaeosalinity and Walker (op. cit.) has reported that the adjusted boron content of illites from two supposed freshwater limestones from the Middle and Upper Purbeck was similar to that for illite from the marine Middle Purbeck Cinder Bed.

Equivalent boron is now considered to be a realistic index of palaeosalinity (Walker and Price, 1963). Illite from the Upper Purbeck Viviparus beds contains 390 p.p.m. equivalent boron and illite from a Middle Purbeck, supposed freshwater limestone with ostracods contains 380 p.p.m. equivalent boron. These values are comparable to the equivalent boron content of 405 p.p.m. for illite from the marine Middle Purbeck Cinder Bed and to the equivalent boron content of many illites from marine Carboniferous rocks (Walker, 1964). Thus, the geochemical evidence continues to indicate that two limestones in the Middle and Upper Purbeck, previously interpreted as freshwater, were laid down in a marine environment.

The re-interpretation of the salinity environment of the Lower Purbeck faunas as marine by Brown, together with the geochemical evidence for normal marine palaeosalinity at higher Purbeck horizons indicates that a critical re-examination of the evidence for the supposed freshwater origin of much of the Purbeck Formation is required.

Department of Geology,

C. T. WALker.

\footnotetext{
UNiversity College of Wales, ABERYSTWYTH, WALES.
}

18th February, 1964. 


\section{REFERENCES}

WALKER, C. T., 1962. Separation techniques in sedimentary geochemistry illustrated by studies of boron. Nature, Lond., 94 (4833), 1073-1074.

1963. Size fractionation applied to geochemical studies of boron in sedimentary rocks. J. Sediment. Petrol., 33, 694-702.

PRICE, N. B., 1963. Departure curves for computing paleosalinity from boron in illites and shales. Bull. Amer. Ass. Petrol. Geol., 47, 833-841.

1964. Paleosalinity in the Upper Visean Yoredale Formation-Geochemical method for locating porosity. ibid., 48, 207-220.

\section{AGE OF THE ALPINE FOLDS OF SOUTHERN ENGLAND}

SIR,--In a recent letter Butcher (1963) considered that the presence of thick Tertiary strata north of the Brixton Anticline implies that this thickness together with the thickness of the missing part of the Cretaceous strata has been eroded away south of the steep limb. He suggested that with so much erosion on the south, yet even more Tertiary strata must have existed on the north side so that an equal degree of erosion could have taken place there. This avoids the idea of a steep-sided mountain of Tertiary strata, several thousand feet high. If, however, the folding was slow with erosion taking place simultaneously only over the axis this problem does not arise.

Butcher, however, states that the Alpine monoclinal folds could have been produced in less than one million years but there is much evidence that the

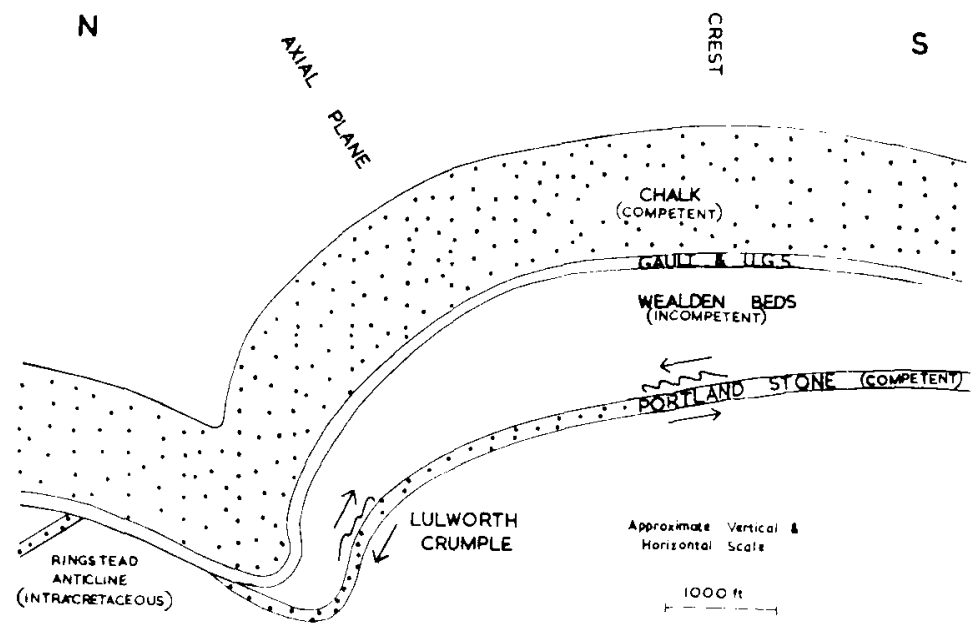

Alpine monoclinal folding of southern England occupied a considerable length of time with partial erosion of the folds taking place as they rose.

First east-west folding had been taking place in the Chalk of southern England before deposition of the Tertiary Beds. In Dorset, north of the Purbeck Monocline and the en échelon Chaldon-Poxwell-Ridgeway structures, which involved both monoclinal folding and faulting, the Tertiary Beds bear evidence of early Tertiary uplift and erosion of local structures. At East Lulworth and Morden the Reading Beds contain both flint pebbles and Upper Greensand chert (Reid, 1896) while the Bagshot Gravels at Morton and Black Down (Hardy's Monument) also contain Purbeck chert and limestone (Reid, 1896; Arkell, 1947). As Reid pointed out, westward overstepping of the Jurassic Beds by the Upper Greensand necessitates a local 